\title{
Quadrohelix Model in the Implementation of Labor Training on the Work Training Center of DKI Jakarta
}

\author{
Endang Wirjatmi Trilestari*, Saekul Anwar \\ Polytechnic STIA LAN Bandung \\ Bandung, Indonesia \\ *e.wirjatmi01@gmail.com
}

\author{
Siti Jamharoh \\ The Department of labor, Energy and Transmigration \\ Jakarta, Indonesia
}

\author{
Endang Wiryantiningsih \\ The Ministry of Village of the Republic of Indonesia \\ Jakarta, Indonesia
}

Lukmanulhakim Almamalik

Politeknik Piksi Ganesha Bandung Bandung, Indonesia

\begin{abstract}
Open unemployment in DKI Jakarta has been increasing from year to year. The current condition is getting higher during the Covid 19 pandemic. This is a result of the reduction in the formal sector. Facing this problem, the government is obliged to find a solution for the affected community with the presence of Job Creation Law. However, the government's ability to assist job seekers to find jobs according to their competence also faces limitations. Collaboration in organizing training with the private sector and the community to improve the skills of job seekers has not been effective. The idea of measuring the effectiveness of collaboration between parties related to the Quadro helix concept is the main attraction in this study. Quad helix involves local governments, universities, communities, and business actors. This study was conducted using systems thinking and system dynamics approach to describe the effectiveness of stock and flow training conducted by the Central Jakarta Regional Job Training Center.
\end{abstract}

Keywords—quadro helix, unemployment, training

\section{INTRODUCTION}

Covid 19 is an event that changes the way people live. Changes that have an impact on the increase of the unemployment rate. The number of unemployed in Indonesia keeps increasing due to this virus. In August 2020, it reached 9.77 million people, increasing 2.67 million compared to 2019 . There are differences in the number of unemployed in urban and rural areas. The condition showed that the Open Unemployment Rate (TPT) increased by $7.07 \%$. This condition is higher than in August 2019 with a position of 5.23\%.

The biggest open unemployment rate was in urban areas which reached $8.89 \%$ while in rural areas was $4.71 \%$. The city with the highest unemployment rate is Jakarta, reaching $10.95 \%$, while the lowest is in West Sulawesi. This open unemployment will increase with an increase in the workforce. The number of labor force per August 2020 increased by 2.36 million people to 138.22 million. However, the number of people working decreased by 310,000 as stated by the Head of BPS Suharyanto, Jakarta DDTC News- November 5 ${ }^{\text {th }}, 2020$. This condition is expected to increase with the decrease in community activities.

This increase in the unemployment rate has led to an increase in job seekers. However, the large number of job seekers also increases the community's motive to create jobs. Surely, this condition requires suitable skills for job seekers and job creators themselves. Cities are the main destination for job seekers. However, the ability to provide job training in the DKI Jakarta area is also limited. Therefore, it cannot meet the needs of job training for the community.

The potential for collaboration to provide skills for the jobseeking community has begun to be exploited. However, it is not optimal yet and only limited to private companies. Other elements that have the potential to assist in the delivery of job training have not been utilized properly. These potentials include private companies, businesses owner, universities, and non-governmental organizations in the DKI Jakarta area that have the potential to collaborate.

\section{A. Problems Faced in Improving the Skills of Job Seekers}

Job seekers are people who need work to earn income, both people who have never worked or who have been laid off (PHK). In general, they do not have the skills to enter the job market or new skills that are suitable for new jobs.

Currently, most of the job training for Job Seekers at PPKD DKI Jakarta is still carried out by PPKD DKI Jakarta. Limited availability of facilities, infrastructure, budgets, and manpower trainers has resulted in the lack of job training to able to address and fulfill the training needs of job seekers who want to receive training. 
To optimize the Job Training, PPKD DKI Jakarta needs to seek breakthroughs and innovations to synergize and coordinate existing training in the community and industry by utilizing both facilities, trainers, and funding from industry and society. Apart from that, PPKD DKI Jakarta must actively invite the University to be able to implement the Three Mission of Higher Education in the form of this training. The collaboration between Local government and universities as driving force for innovation is supported by Aranguren [1]

Based on the phenomena above, the writers try to discuss how the implementation of the Quadro helix model collaboration carried out by the DKI Jakarta government in increasing the implementation of job training for the job seeker community. The objectives of this research are to find new ways to help the DKI government in reducing the burden of implementation of increasing the competence of job seekers in the DKI Jakarta area by using a collaborative Quadro-helix model in providing skills for job seekers to reduce unemployment.

\section{B. The Concept of Quadro-helix as a Problem-based Approach}

The research was carried out based on some of the deficiencies in the triple helix concept that had been introduced by Leydesdorf and Etzkowitz [2], Etzkowitz, and Leydesdorff [3]. It was stated that the triple-helix concept does not include the role of elements of society. In its development, Quadrohelix is a form of collaboration of 4 elements that have different functions to achieve the same goal [4]. The finding by Setyanti was also supported with the research conducted by Schütz F., et.al [5] which stated that Quadro Helix involved four major actors, namely science, policy, industry, and society. Collaboration in the form of triple helix in innovation systems has been studied in the past few years. Leydesdorf and Etzkowitz [2], Leydesdorf [6]; Leydesdorf and Park [7] have opened knowledge on the importance of collaboration between government, the business sector, academics, and the community as a center. In contrast to the research conducted by Irena Vaivode [8], which observed the contribution of R \& D activities by using the triple helix as a source of innovation, in which the community was not included, this thinking makes society an amplifier in the Quadro helix as the point of view of his research.

It is also assumed that the Quadro helix is a collaboration that provides a driving force for the community to participate in increasing the competence of the job seeker community as implied by Feran J.G., and Skoglund [9] Therefore, in this study it is also questioned, why in this paper uses the Quadro helix approach? At the time the Triple helix concept was used to improve the competence of the job seeker community, it was not included as part of the helix that was the subject. The Värmland County Administrative Board has added elements of society as a subject to improve their society. In this study, the community is seen as government subject that must be served. Therefore, this paper uses the Quadro helix concept to promote the job-seeking community.

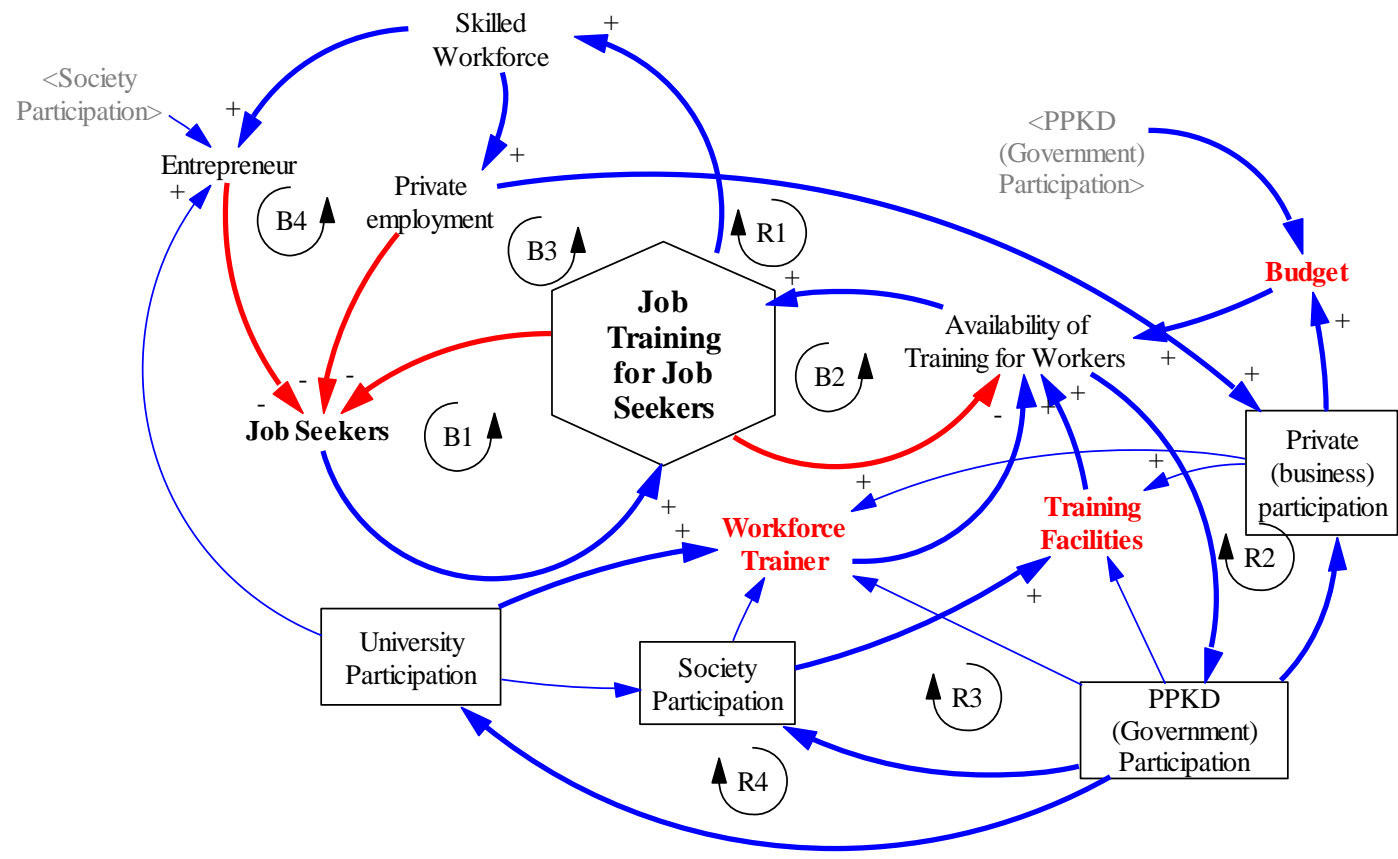

Fig. 1. Causal loop model relationship diagram in Quadro Helix. 
The framework can also be defined in several ways depending on the context of the four helixes arena. The four helixes are contained in elements that can directly support the dynamics of the relationship between the helix in accordance with the added value activities required by the community. Thus, increasing community competence is needed to improve work competence. It is supported by the ability of the DKI Jakarta government in this case is PPKD DKI Jakarta, universities as providers of trainers and the private sector as laboratory facilities and users of skilled workforce that are produced into one unit. For this reason, the basic concept is to initiate the research to be carried out by presenting the causal loop diagram model as shown in Figure 1.

The relationship between the helix in the Quadro helix above are used as the basis for the analysis in this study. The linkages in the four helixes in this concept require collaboration between them, as done by Scott Reeves, Andreas Xyrichis, and Merrick Zwarenstein [10]. Collaboration can be in the form of Interprofessional teamwork, Interprofessional collaboration, and Interprofessional networks. Among the four helixes, it is expected that teamwork is formed, where each helix has a clear identity of the goal to be achieved, and between them individually need each other. Team collaboration in the form of Interprofessional teamwork also requires facilities for conducting Interprofessional collaboration, which means that there are facilities to understand the needs for increasing community competence following the fields that will be in it. The business world is a provider of employment or those that have skills training laboratories and the government as a liaison between helix and training facility providers, plus universities as providers of training materials and trainers.

\section{METHODS}

In this paper, the research used is a systems approach. The complexity of the problem lies in the variety of skills needed because the problem is complex and dynamic. The complexity of the problem by conducting job training in the community cannot be solved linearly. Therefore, the approach used is soft and hard systems thinking which is simulated by using vensim PLE®8.1.0 (Double Precision) [6].

Systems thinking is an approach to solving unstructured problems (Peter Chekland) and system dynamics is used to measure the dynamics of change in a system.

The problems faced in helping solve problems through improving the competence of the job seeker community are complex. The complexity of this problem lies in the level of ability of the four helixes to collaborate to achieve a common goal. The approach used in this research is systems thinking.
The complexity of this research indicated that there are at least four elements in the Quadro-helix that will be the focus in organizing skills improvement training for the job seeker community. These four elements are connected in a causal loop. In detail, the causal elements involved, namely training registrants, training fulfillment needs, and training capacity. These three elements become variables for which the level of performance will be measured. These three elements produce the performance of the 4 helices, namely the helix of the government's role as a training provider in collaboration with the second helix, namely the role of the job seeker community and the role of universities that help resources in the form of learning tools and learning staff and the private sector as a practice place for the training process. The success in providing training is measured using stock and flow diagrams, as evidence of participation in each helix of the Quadro helix in this analysis. Meanwhile, to find out the contribution of each role of the helicopters above, it is processed using a dynamics system. Why are dynamics systems used? System dynamics is a measurement method that is sensitive to changes when simulated.

\section{RESULTS AND DISCUSSION}

To solve the four-helix problems in improving the Quadrohelix Model of the Implementation of Labor Training in The Work Training Center of Central Jakarta Regional, which has been modeled above, the analysis used was stock and flow diagrams.

The results showed the efforts made by the DKI Jakarta Government in increasing skilled labor through collaborative training with the Quadrohelix model. It showed the limit to growth and growth and under-investment system models. The limit to growth is due to limited resources: facilities, funds, and trainers. Limit to growth is due to an imbalance between the growth of the workforce that requires work skills that are limited by the capacity of the above resources as stated by Rafael [11] and Radim [12].

Stock and flow diagrams for the Quadro Helix model for Job Training for Job Seeking Communities in PPKD DKI Jakarta are presented in Figure 2_Diagram. This model was built using the System Dynamics methodology referring to Rafael [11]. The model consists of three Stock variables: Training Registrants, Training Fulfillment Needs, and Training Capacity. This model also presents additional variables, parameters, and model equations that are built from references or estimates, as shown in Figure 2. For model simulations, the model simulation time is carried out for 10 years from 2008 to 2018 using the Vensim PLE software. 


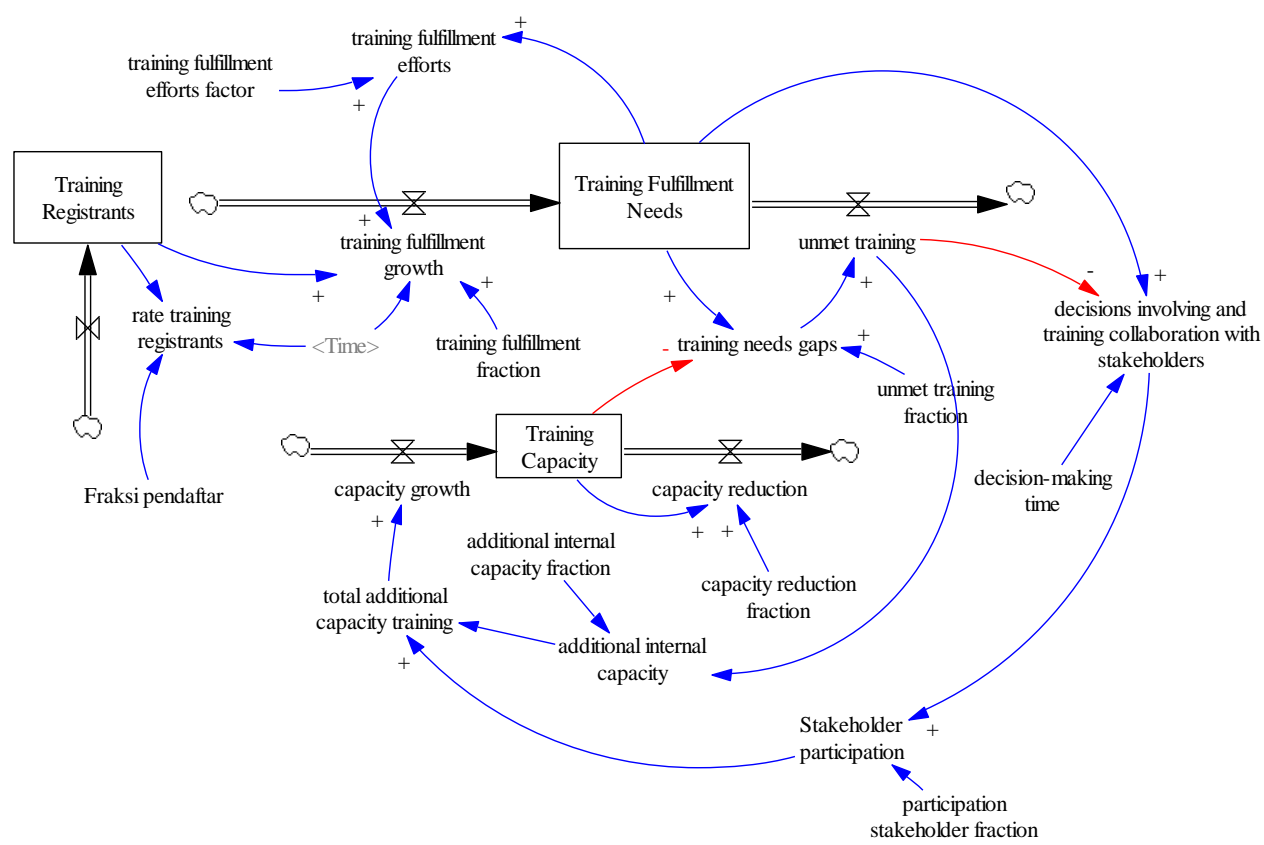

Fig. 2. 2 Stock and flow diagram of quadro helix job training for job seekers community in PPKD DKI Jakarta.

The Quadro Helix Problem in Job Training for Job Seeking Communities in PPKD DKI Jakarta can be solved using the basic pattern of the Growth and Underinvestment system. The Growth and Undergraduate Model of this research problem refers to Setyanti [4] and Schütz F., et.al. [5]. From Figure 2, The Need for Fulfillment of Job training at PPKD DKI Jakarta continues to experience growth. However, the need for this training fulfillment cannot continue to grow due to the limited training capacity that the PPKD of DKI Jakarta has in the form of budget, facilities, and infrastructure as well as its trainer staff. Training Fulfillment Needs, training fulfillment efforts, and training fulfillment growth are all forms of strengthening that will encourage the system to grow, while Training Fulfillment Needs, training needs gaps, and unmet training are balancing loops that will reduce system growth.

Furthermore, if the system is expanded, for example, to overcome the limitations of the Fulfillment of Training Needs, PPKD DKI Jakarta increases the Training Capacity which is represented by a balancing loop of the Training Capacity variable, the gap in training needs, unfulfilled training, additional internal capacity, total training capacity, and capacity growth. This model also adds a reinforcement loop to reveal the involvement of private companies, communities that own businesses, universities, and non-governmental organizations in the DKI Jakarta area that have the potential to carry out training collaborations.
Labor Training at PPKD DKI Jakarta

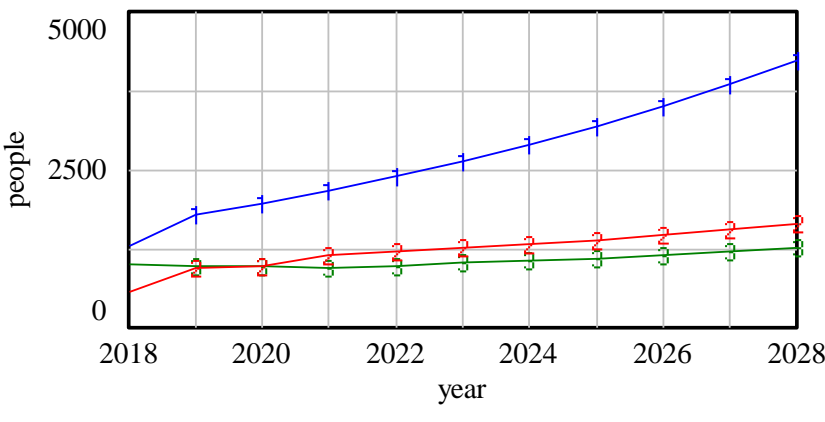

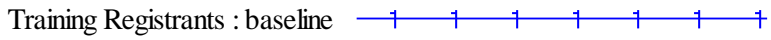
Training Fulfillment Needs : baseline $\begin{array}{lllllll}2 & 2 & 2 & 2 & 2\end{array}$ Training Capacity : baseline $\begin{array}{lllllll}3 & 3 & 3 & 3 & 3 & 3\end{array}$

Fig. 3. Model simulation results at baseline conditions.

Figure 3 shows the simulation results of the Quadro Helix model of Job Training for Job Seeking Communities in PPKD DKI Jakarta in basic conditions. From Figure Graph 1, if the job training for the job seeker community at PPKD DKI Jakarta only relies on the ability and training capacity as they currently have, then the number of training applicants who can be fulfilled/included in the training on average is only around $47 \%$.

Figure 4 shows the results of the model simulation when the training capacity building factor is increased, showing an increase in the ability to provide training. However, the increasing need for people who need training is very high. In this simulation, PPKD DKI Jakarta continues to strive to increase its own training capacity/ability and has not fully 
involved the participation of stakeholders (Quadro-helix). In this simulation, the value of the training capacity building factor is increased from $50 \%$ to $150 \%$ of the unmet training needs (gap in training needs). The results of the Model Simulation by changing the value of the training capacity building factor by PPKD DKI Jakarta can be seen that by only increasing the training capacity of $150 \%$ from the existing training need gap, the training applicants can be included an increase to $52.3 \%$. There was an increase in the addition of participants by an average of $5 \%$ from baseline conditions.

\section{Labor Training at PPKD DKI Jakarta}

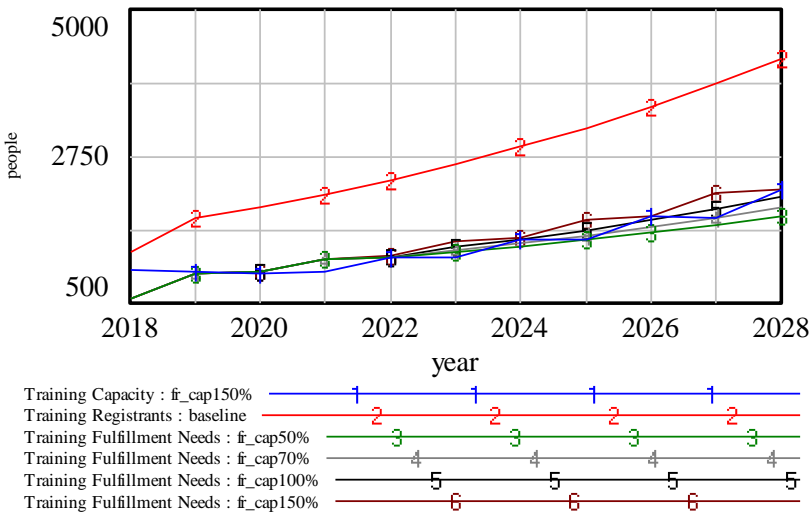

Fig. 4. Model simulation results by changing the value of the factor for increasing training capacity by PPKD DKI Jakarta.

\section{Labor Training at PPKD DKI Jakarta}

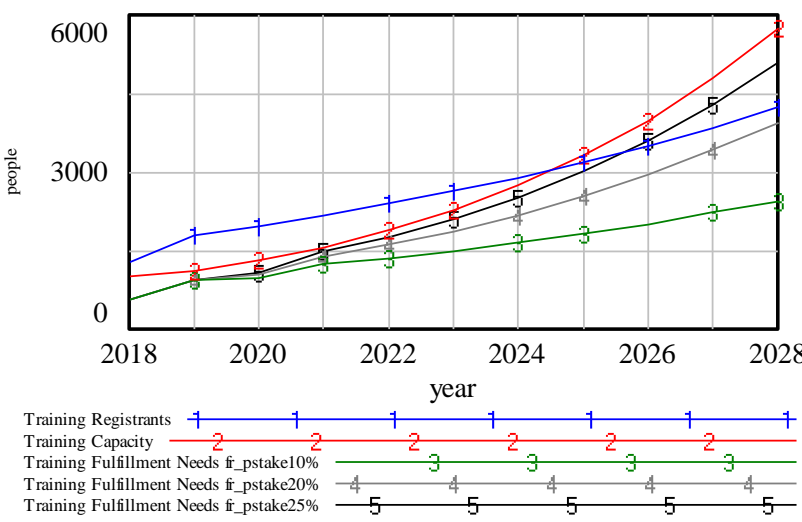

Fig. 5. Model simulation results for various values of the role factor of the Stakeholder (Quadrohelix)

Figure 5 shows the simulation results of the ethical model of the role of stakeholders (private, community, and Universities) which are involved and working together in job training activities at PPKD DKI Jakarta. In this simulation, the stakeholder role factor value is changed from $10 \%$ to $25 \%$ of the total unfulfilled participant training (registered training participants who have not been able to be included). The assumption is that the training activities carried out are not only in PPKD DKI Jakarta, but may be scattered in training locations in companies, universities, or the community and with funding assistance from stakeholders. From Figure 5, the graph can be seen that when the PPKD DKI Jakarta is successful in collaborating and involving the participation of stakeholders in conducting job training activities, then the training applicants who can be included will continue to experience an increase and can be included entirely. The speed at which PPKD DKI Jakarta can fulfill the training registration participants depends on the size of the participation of stakeholders and the speed of cooperation time (MOU) between PPKD DKI Jakarta and stakeholders, especially the private sector and the community. From Figure 5, the graph of the simulation results can be seen, if the stakeholder participation factor is $25 \%$, it is expected that by 2025 all training applicants at PPKD DKI Jakarta will be included in the training.

\section{CONCLUSION}

This study illustrates that the growing need for skills improvement is increasing in the DKI Jakarta area. The ability of PPKD is a pillar for the community. The participation of tertiary institutions as providers of trainers and training materials and the private sector as training laboratories and job providers has an indispensable role. Even though it has not been running optimally recently. In the simulation, if the four roles are optimized, it will get a balance (balancing loop) in the future. For this reason, it is recommended that the head of PPKD DKI Jakarta collaborate continuously with the helixes above, to maintain stability in the preparation and availability of job seekers and job opportunities that are created.

\section{REFERENCES}

[1] M.J. Aranguren and M. Larrea, "Regional innovation policy processes linking learning to action," Journal of the Knowledge Economy, vol. 2 no. 4, pp. 569-585, 2011.

[2] L. Leydesdorff and H. Etzkowitz, "Emergence of a Triple Helix of university-industry_-government relations," Science and public policy, vol. 23, no. 5, pp. 279-286, 1996.

[3] H. Etzkowitz and L. Leydesdorff, "The dynamics of innovation: from National Systems and "Mode 2" to a Triple Helix of universityindustry-government relations," Research policy, vol. 29, no. 2, pp. 109 $123,2000$.

[4] S.W.L.H. Setyanti, "The Quadruple Helix Model: Enhancing Innovative Performance Of Indonesian Creative Industry," International Journal Of Scientific \& Technology Research, vol. 6, issue. 11, 2017.

[5] F. Schütz, M.L. Heidingsfelder, M. Schraudner, she ji The Journal of Design, Economics, and Innovation, vol. 5, no. 2, 2019.

[6] L. Leydesdorff, "The mutual information of university-industrygovernment relations: An indicator of the Triple Helix dynamics,' Scientometrics, vol. 58, pp. 445-467, 2003.

[7] L. Leydesdorff and H.W. Park "Can synergy in Triple Helix relations be quantified? A review of the development of the Triple Helix indicator," Triple Helix, vol. 1, no. 1, pp. 1-18, 2014.

[8] I. Vaivode, "Triple Helix Model of university-industry-government cooperation in the context of uncertainties," 20th International Scientific Conference Economics and Management - 2015 (ICEM-2015), 2015. 
[9] J.G. Feran and A. Skoglund, "A Processual Approach for the Quadruple Helix Model: the Case of a Regional Project in Uppsala," J Knowl Econ, vol. 10, pp. 1272-1296, 2019.

[10] S. Reeves, A. Xyrichis, and M. Zwarenstein, "Teamwork, collaboration, coordination, and networking: Why we need to distinguish between different types of interprofessional practice," Journal Of Interprofessional Care, vol. 32, no. 1, pp. 1-3, 2019.
[11] R.E. Bourguet-Díaz and G. Pérez-Salazar, "On Mathematical Structures for Systems Archetypes", 2003, [online] reftrieved from https://www.researchgate.net/publication/237651064_On_Mathematical _Structures_for_Systems_Archetypes last accessed, November 2020.

[12] R. Spicar, "System Dynamics Archetypes in Capacity Planning," Procedia Engineering, vol. 69, no. 2014, pp. 1350-1355, 2014. 